\title{
Analisis Capaian Perkembangan Sosial Anak Usia 11 Bulan Berdasarkan Standar Tingkat Pencapaian Perkembangan Anak
}

\author{
Eka Damayanti ${ }^{1}$, Umaemah Marsuki AR ${ }^{2}$, Ismawati ${ }^{3}$ \\ 1,2,3 UIN Alauddin Makassar
}

DOI : https://doi.org/10.15642/jeced.v2i2.686

\begin{abstract}
This study aims to determine the criteria for social development in children 11 months based on the Standard Level of Child Development Achievement and formulate appropriate stimulation based on the theory of child development. The research was conducted using a descriptive qualitative approach. The research subjects were two children aged 11 months who were selected by purposive sampling. The data were collected from observation and direct interview techniques then analyzed descriptively. The results showed that both children (HM and D) had met the age standard in terms of research desires with various body movements and simple word expressions, how to express feelings such as, how to apply and kiss. The forms of stimulation performed by parents or caregivers of children include: (1) building attachment with children; (2) invite the child to have a conversation or A with the closest person; and (3) inviting children to play with their peers.
\end{abstract}

\section{Article Info \\ Article history:}

Received: September 28, 2020

Approved: December 28, 2020

Published online: December 31, 2020

Keywords:

social developmental aspects, stimulation, early childhood, standard level of child development achievement

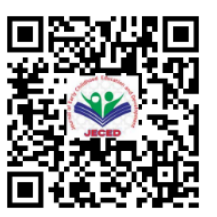

\begin{abstract}
Abstrak
Penelitian ini bertujuan untuk mengetahui pencapaian aspek perkembangan sosial pada anak usia 11 bulan berdasarkan Standar Tingkat Pencapaian Perkembangan Anak dan merumuskan stimulasi yang tepat berdasarkan teori perkembangan anak. Penelitian dilakukan menggunakan pendekatan kualitatif jenis deskriptif. Subjek penelitian sebanyak dua anak yang berusia 11 bulan yang dipilih secara purposive sampling. Pengumpulan data yang digunakan menggunakan teknik observasi dan wawancara secara langsung. Hasil penelitian menunjukkan kedua anak (HM dan D) telah memenuhi standar usia dalam hal menyatakan keinginan dengan berbagai gerakan tubuh dan ungkapan katakata sederhana, meniru cara menyatakan perasaan seperti cara memeluk dan mencium. Bentuk stimulasi yang dilakukan orangtua atau pengasuh anak berupa: (1) membangun kelekatan dengan anak; (2) mengajak anak bercakap-cakap atau berinteraksi dengan orang terdekat; dan (3) mengajak anak untuk bermain dengan teman sebayanya.
\end{abstract}

\begin{tabular}{l}
\hline Informasi Artikel \\
\hline Riwayat Artikel \\
Diterima: 28092020 \\
Disetujui: 28122020 \\
Publikasi online: 31122020 \\
\hline Kata kunci: \\
aspek perkembangan sosial, stimulasi, \\
anak usia dini, standar tingkat \\
pencapaian perkembangan anak
\end{tabular}




\section{PENDAHULUAN}

Anak usia dini merupakan anak dengan rentang usia 0-6 tahun atau bisa disebut dengan masa keemasan (golden age). Anak usia dini adalah kelompok anak yang berada dalam tahap pertumbuhan dan perkembangan yang memiliki karakteristik tertentu. Setiap anak memiliki pola pertumbuhan dan perkembangan yang khas sesuai dengan tingkat usianya baik itu dalam aspek perkembangan moral dan agama, fisik motorik, sosial emosional, kognitif, bahasa dan komunikasi (Suhano \& Utama, 2017). Berdasarkan Peraturan Menteri Pendidikan dan Kebudayaan Nomor 137 Tahun 2014 tentang Standar Nasional Pendidikan Anak Usia Dini menyatakan pendidikan anak usia dini adalah upaya pembinaan yang ditujukan kepada anak sejak lahir sampai usia enam tahun yang dilakukan melalui pemberian rangsangan pendidikan untuk membantu pertumbuhan dan perkembangan jasmani dan rohani agar anak memiliki kesiapan dalam memasuki pendidikan lebih lanjut. Terdapat enam aspek perkembangan yang harus dikembangkan pada anak usia dini ialah aspek perkembangan nilai agama dan moral, kogniti, sosial emosional, bahasa, fisik motorik, dan seni (Kemendikbud, 2014).

Perkembangan zaman di era globalisasi dan teknologi yang sangat pesat menjadikan pendidikan yang diberikan sejak usia dini sangatlah penting. Anak-anak harus dibekali ilmu pengetahuan yang baik dan benar melalui jenjang pendidikan anak usia dini. Kualitas pendidikan yang baik sangat memerlukan pengembangan sarana dan prasarana yang sesuai dengan tingkat perkembangan anak karena akan berdampak negatif bagi perkembangan anak apabila tidak diseimbangkan dengan peningkatan sumber daya manusia (SDM). Menurut Suherman (2002) pendidikan anak usia dini adalah jenjang pendidikan sebelum memasuki jenjang pendidikan dasar sekaligus menjadi salah satu bentuk penyelenggaraan pendidikan yang menitikberatkan pada peletakan dasar pertumbuhan dan perkembangan fisik yang mana diantaranya koordinasi motorik dan kecerdasan yang meliputi: daya pikir, daya cipta, kecerdasan emosi, kecerdasan spiritual, kondisi sosial emosional (sikap dan perilaku agama) serta bahasa dan komunikasi, sesuai dengan keunikan dan tahap-tahap perkembangan yang dilalui oleh anak usia dini. Sedangkan perkembangan yang dimaksud adalah perubahan psikologis sebagai hasil dari proses pematangan fungsi psikis dan fisik pada diri anak, dilihat dari faktor lingkungan dan proses belajar dalam peredaran waktu tertentu menuju kedewasaan dari lingkungan yang sangat berpengaruh dalam kehidupan anak menuju dewasa.

Va (2016) memaparkan perkembangan anak dari berbagai aspek harus dikembangan dengan baik seperti aspek perkembangan fisik motorik, kognitif, sosial dan emosional, moral dan agama serta seni. Aspek fisik berkaitan dengan pertumbuhan tubuh dan otak, keterampilan motor, serta kesehatan. Aspek kognitif berkaitan dengan atensi, memori, pemecahan masalah, proses berfikir, kreativitas dan bahasa. Aspek psikososial berkaitan dengan perkembangan emosi, kepribadian, dan hubungan sosial. Sebagai contoh, anak yang terampil bermain piano (aspek fisik-motorik), karena merasa bangga dan unggul di depan teman-temannya (aspek sosial-emosional), dan kreativitas melalui melodi sederhana yang dimainkannya (aspek kognitif).

Perkembangan anak usia dini harus distimulasi secara tepat. Stimulasi merupakan usaha pemberian rangsangan yang dilakukan sejak bayi baru lahir agar perkembangan anak berkembang dengan baik. Menurut Rusmil (2006) stimulasi merupakan pemberian rangsangan kepada anak yang berhubungan dengan kemampuan dasar anak agar dapat berkembang secara optimal. Kemampuan dasar anak harus selalu diasah sedini mungkin dan dilakukan secara terus menerus dengan memberikan stimulasi kepada anak disetiap kesempatan. Menurut Soetjiningsih (2013) pemberian rangsangan kepada anak 
merupakan hal yang penting dalam tumbuh kembang anak karena perkembangan anak akan berkembang dengan baik dan cepat apabila anak selalu diberikan stimulasi yang terarah serta teratur dibandingkan dengan anak yang jarang atau yang kurang distimulasi. Stimulasi yang diberikan kepada anak harus sebanding baik dari segi kualitas maupun kuantitas serta harus sesuai dalam tingkat kematangan saraf anak.

Pemberian stimulasi sangat penting bagi anak sejak usia dini agar dapat berkembang dengan optimal dalam berbagai aspek perkembangan. Pemberian stimulasi tetap diberikan sesuai dengan tahapan usia perkembangan sehingga anak tidak merasa terbebani (Hasiana et al., 2020). Menurut Putra et al., (2018) bahwa tiga tahun pertama kehidupan anak merupakan masa-masa krusial karena perkembangan otak anak berkembang sangat pesat. Oleh karena itu, pemberian stimulasi pada tiga tahun pertama kehidupan anak merupakan hal yang sangat penting. Dalam mengembangkan berbagai potensi yang dimiliki oleh anak secara holistik baik pada aspek pendidikan, gizi maupun kesehatan tentu melalui pemberian rangsangan. Pemberian stimulasi, cara pengasuhan dan pemberian makan sangat menentukan dalam pertumbuhan otak anak pada anak usia dini yang biasa disebut periode kritis (critical period) (Permono, 2013). Potensi-potensi yang dimiliki oleh anak akan berkembang dengan baik apabila orangtua memahami stimulasi apa yang tepat diberikan kepada anak. Oleh karena itu, penting bagi orangtua untuk mengetahui serta memahami perkembangan anak agar dapat memberikan stimulasi yang tepat sesuai dengan kebutuhan anak karena masa kanak-kanak merupakan masa yang sangat menentukan arah kehidupan manusia. Setiap anak mempunyai karakteristik dan potensi-potensi yang menjadi dasar bagi pertumbuhan anak di kehidupan kedepannya (Sulfa \& Setiawan, 2018).

Metode stimulasi, jenis stimulasi, waktu atau intensitas stimulasi, fasilitas atau media stimulasi merupakan standarisasi untuk memaksimalkan stimulasi ibu terhadap perkembangan anak. Kurangnya stimulasi karena banyaknya ibu yang belum memahami tentang perannya dalam memberikan stimulasi pada anak, maka akan menghambat pertumbuhan serta perkembangan anak itu sendiri. Pada kenyataannya, melalui stimulasi anak dapat mencapai perkembangan secara optimal pada aspek sosialnya (Mitayani \& Nursetiawati, 2015)

Perkembangan anak akan berkembang secara optimal apabila orang tua memberikan stimulasi kepada anak sesuai dengan tingkat usia anak. Kemampuan tumbuh kembang anak perlu dirangsang oleh orang tua agar anak dapat tumbuh dan berkembang secara optimal dan sesuai umurnya. Pentingnya stimulasi pada anak usia dini menjadi dasar dari tulisan ini dibuat. Tulisan ini fokus mengkaji mengenai stimulus aspek perkembangan sosial anak yang berusia 11 bulan dengan mengamati apakah anak tersebut berkembang sesuai dengan tingkat pencapaian anak. Stimulasi yang dimaksud berupa stimulasi visual (penglihatan), verbal (bicara), auditif (pendengaran), taktil (sentuhan) yang datang dari lingkungan anak.

\section{METODE}

Metode pengumpulan data yang digunakan dalam mengumpulkan data menggunakan pendekatan kualitatif jenis deskriptif. Subjek penelitian sebanyak dua orang anak (HM dan D) yang dipilih secara purposive sampling berdasarkan kriteria: (1) anak usia dini usia 11 bulan; (2) mudah dijangkau oleh peneliti; (3) orangtuanya menyatakan kesediaan menjadi informan dan menyatakan anaknya dapat diobservasi. Penelitian dilakukan melalui observasi secara langsung selama tiga bulan yakni Maret Mei 2020. 
Data dikumpulkan menggunakan teknik observasi dan wawancara. Peneliti sebagai instrumen kunci menggunakan bantuan pedoman observasi dan wawancara yang disusun berdasarkan indikator tingkat pencapaian perkembangan anak berdasarkan dalam Peraturan Menteri Pendidikan dan Kebudayaan Republik Indonesia Nomor 137 Tahun 2014 tentang Standar Nasional Pendidikan Anak Usia Dini, khususnya pada aspek perkembangan sosial anak usia 11 bulan. Pertama, menyatakan keinginan dengan berbagai gerakan tubuh dan ungkapan kata-kata sederhana, ditandai dengan kemampuan yakni (1) mengucapkan kata "eggi" jika ingin pergi; (2) menyimpan tangan di kepala sambil tersenyum. Kedua, menirukan cara menyatakan perasaan, ditandai dengan kemampuan yakni (1) memeluk orang tua; (2) mencium orang tuanya ketika lagi bahagia.

Data yang dikumpulkan selanjutnya dianalisis dengan cara menarasikan secara deskriptif dengan menggambarkan secara lengkap dan menyeluruh hasil observasi dan wawancara berdasarkan indikator tingkat pencapaian perkembangan sosial anak. untuk menjaga keabsahan data supaya hasil penelitian ini memenuhi standar derajat kepercayaan, maka peneliti lakukan (1) memperpanjang pengamatan, dilakukan dengan penelitian selama tiga bulan; (2) ketekunan pengamatan, dilakukan dengan memperhatikan perbedaan secara detail tiap capaian perkembangan dan peneliti juga memberikan stimulus jika capaian perkembangan tidak muncul pada saat observasi dan wawancara dilakukan; (3) triangulasi, dilakukan dengan membandingkan data hasil observasi dengan data wawancara, selain itu juga membandingkan temuan pada anak dengan hasil wawancara dari orang tua anak.

\section{HASIL PENELITIAN DAN ANALISIS}

Tingkat pencapaian perkembangan anak pada aspek sosial di usia 9-12 bulan. Pada perkembangan sosial terdapat dua indikator yang meliputi: (1) dapat menyatakan keinginan dengan berbagai gerak tubuh dan ungkapan kata-kata sederhana; dan (2) meniru cara menyatakan perasaan (mencium dan memeluk). Berdasarkan hasil penelitian yang dilakukan oleh peneliti dari dua subjek (HM dan D), maka didapatkan gambaran hasil perkembangan sosial yang berbeda-beda. Secara jelas, hasilnya dapat dilihat pada table 1.

Tabel 1. Subjek dan Indikator

\begin{tabular}{llll}
\hline Subjek & \multicolumn{2}{l}{ Indikator } & \\
\hline HM & Pencapaian & $\begin{array}{l}\text { Dapat menyatakan keinginan } \\
\text { dengan berbagai gerak tubuh } \\
\text { dan ungkapan kata-kata } \\
\text { sederhana } \\
\text { Mengucapkan kata sederhana }\end{array}$ & $\begin{array}{l}\text { Meniru cara menyatakan } \\
\text { perasaan (mencium dan } \\
\text { memeluk) }\end{array}$ \\
& Stimulasi & $\begin{array}{l}\text { Anak mencium dan memeluk } \\
\text { orangtua ketika hendak berbaring }\end{array}$ \\
& Orangtua & $\begin{array}{l}\text { Mengajak anak untuk } \\
\text { bercakap-cakap atau } \\
\text { berinteraksi dengan orang } \\
\text { terdekat }\end{array}$ & $\begin{array}{l}\text { Membangun kelekatan dengan } \\
\text { anak }\end{array}$ \\
& Pencapaian & $\begin{array}{l}\text { Hanya menunjuk tapi sudah } \\
\text { memahami }\end{array}$ & $\begin{array}{l}\text { Memeluk orang yang } \\
\text { menggendongnya }\end{array}$ \\
& Stimulasi & $\begin{array}{l}\text { Mengajak anak untuk bermain } \\
\text { dengan teman sebayanya }\end{array}$ & $\begin{array}{l}\text { Membangun kelekatan dengan } \\
\text { anak }\end{array}$ \\
\hline
\end{tabular}

Sumber: Diolah sendiri peneliti 
Pada aspek perkembangan sosial untuk indikator pertama, dapat menyatakan keinginan dengan berbagai gerak tubuh dan ungkapan kata-kata sederhana, HM dan D sudah mampu menyatakan ungkapan kata-kata sederhana. Terlihat ketika HM mengucapkan kata sederhana seperti "eggi" ketika hendak pergi sedangkan D, hanya memberikan kode dengan cara menunjuk kearah yang ingin dituju. Untuk indikator kedua, meniru cara menyatakan perasaan seperti dengan cara (mencium dan memeluk), HM dan D mampu menyatakan perasaannya dengan cara memeluk dan mencium orangorang terdekatnya, terlihat ketika D melihat ibunya berbaring, D menghampiri ibunya kemudian mencium dan memeluknya sedangkan HM menyatakan perasaannya dengan cara memeluk, terlihat ketika sedang digendong dengan orang-orang terdekatnya, maka HM langsung memeluk orang yang sedang menggendongnya.

Kasus diatas menggambarkan tingkat pecapaian dan perkembangan pada aspek perkembangan sosial pada kedua anak telah terpenuhi. Ditandai dengan hasil observasi dengan memberikan stimulus yang tepat dengan standar tingkat pencapaian dan perkembangan serta pemilihan usia yang tepat sehingga menghasilkan perilaku yang menggambarkan berhasilnya indikator tersebut. Pada dasarnya semua anak memiliki potensi pada dirinya, tetapi lingkunganlah yang membantunya agar dapat mengembangkan potensi tersebut. HM dan D memiliki potensi yang sangat besar pada dirinya salah satunya pada aspek sosial dan mampu memenuhi standar tingkat pencapaian perkembangan pada aspek perkembangan sosial.

\section{PEMBAHASAN}

Pertumbuhan dan perkembangan pada anak tidak lepas dari konsep tumbuh kembang pada anak. Menurut Adriana (2013) pertumbuhan merupakan perubahan fisik dan meningkatnya ukuran tubuh yang berbeda tiap anak, sedangkan perkembangan merupakan bertambah kemampuan, keterampilan dan fungsi tubuh yang lebih kompleks dalam kecakapan motorik halus, bicara dan bahasa serta sosialisasi dan kemandirian yang dimiliki anak untuk menyesuaikan diri dengan lingkungan sekitar. Menurut Ribek et al., (2013) pada hal aspek tumbuh kembang anak mendapatkan perhatian secara serius karena pada aspek ini mengenai proses pembentukan anak, baik secara fisik maupun psikososial. Perkembangan psikososial sangat dipengaruhi oleh lingkungan dan interaksi antara anak dan orang tuanya atau orang sekitarnya. Menurut Fida \& Maya (2012) perkembangan anak akan optimal apabila interaksi sosial disesuaikan dengan kebutuhan anak pada tahap perkembangannya. Perkembangan anak dapat berlangsung sesuai tahapan usianya, baik melalui rangsangan yang diterima secara langsung dari orang tua, melalui alat permainan, anggota keluarga serta sosialisasi anak dengan orang dewasa maupun teman sebaya di lingkungan tempat tinggal.

Keberhasilan anak dalam mengembangkan aspek perkembangan sosialnya dikarenakan orangtua dan orang-orang terdekat memberikan stimulasi yang tepat pada anak sesuai dengan tingkat usia dan tahap perkembangannya, sehingga aspek perkembangan sosial anak berkembang dengan sangat baik. Bentuk stimulasi atau rangsangan yang diberikan orangtua sesuai dengan indikator perkembangan sosial anak usia 9-12 bulan seperti: (1) membangun kelekatan dengan anak; (2) mengajak anak untuk bercakap-cakap atau berinteraksi dengan orang terdekat; dan (3) mengajak anak untuk bermain dengan teman sebayanya. Menurut Setyowati (2017) stimulasi yang penting diberikan kepada anak berupa perhatian dan kasih sayang orang tua, seperti mencium dan memeluk agar anak merasa nyaman bersama orang tua, bercakap-cakap atau berinteraksi yang dilakukan setiap hari secara terus menerus yang disesuaikan dengan umur 
perkembangannya. Menurut Megawangi (2014) pemberian rangsangan terhadap anak dapat dilihat dari kualitas kelekatan orangtua dalam mengasuh dan mendidik anak. Apriani (2018) mengatakan bahwa untuk melatih perkembangan sosial anak, pengasuh atau orang tua dapat memberikan rangsangan atau stimulasi dengan cara memeluk dan membelai anak agar perkembangan sosial anak berkembang dengan baik. Menurut Eliasa (2011) kelekatan merupakan salah satu bentuk stimulasi yang diberikan ibu kepada anak dengan cara memberikan rasa nyaman, berinteraksi dengan anak dan memenuhi kebutuhan anak sesuai dengan tingkat perkembangannya.

Stimulasi sendiri merupakan salah faktor psikososial yang dapat mempengaruhi perkembangan anak. Stimulasi adalah hal penting dalam tumbuh kembang anak. Anak yang mendapat stimulasi yang terarah dan teratur akan lebih cepat berkembang dibandingkan dengan anak yang kurang atau tidak mendapat stimulasi (RI, 2012). Stimulasi dilakukan dengan rasa cinta dan kasih sayang, pemberian stimulasi menunjukkan sikap dan perilaku yang baik karena cenderung akan mengikuti sikap dan perilaku orang sekitanya, memberikan stimulasi kepada anak sesuai dengan umurnya, melakukan stimulasi dengan cara bermain dan melakukan hal yang menyenangkan tanpa paksaan dan hukuman (Fauzriesa, 2018). Pemberian stimulasi pada anak erat kaitannya dengan peran orang tua. Peran orang tua dalam memberikan stimulasi dini sangat bermanfaat untuk mengoptimalisasikan tumbuh kembang anak pada aspek fisik, mental dan sosial (Hati \& Lestari, 2016). Sependapat dengan Sumiyati (2016) stimulasi adalah hal yang terpenting bagi perkembangan anak. Semakin cepat anak mendapatkan stimulasi yang teratur dan terarah maka semakin besar tingkat perkembangannya dibanding dengan anak yang tidak atau kurang mendapat stimulasi.

Tampak dalam penelitian ini ketika D pertamakali melihat seseorang, anak itu akan menangis ketika diambil oleh orang lain. Hal ini menunjukkan bahwa kelekatan anak terhadap orang tua atau pengasuhnya sudah mulai terbentuk sehingga jika ada orang lain yang baru didekatnya maka anak akan mencari figure lekatnya. Menurut Hardiyanti (2017) kelekatan yang dibentuk pada bayi tidak terjadi secara otomatis tetapi melalui proses timbal balik antara caregiver (ibu/pengasuh) dengan anak. Menilik pada teori psikososial Erikson, pada usia 0-2 tahun dalam rangka membentuk basic trust pada bayi, yang dibutuhkan adalah kontak dengan bayi berlangsung secara berkesinambungan. Jika bayi sudah membentuk basic trust maka bentuk kelekatan yang akan dikembangkan adalah bentuk kelekatan yang aman. Bayi akan merasa leih nyaman dengan lingkungannya dan saat ditinggal oleh caregiver (ibu/pengasuh) bayi tidak akan rewel karena tahu bahwa caregivernya akan kembali. Masa bayi yang dikemukakan Erikson adalah masa trust mistrust yaitu tahap psikososial yang terjadi selama tahun pertama kehidupan. Rasa percaya menuntut perasaan nyaman secara fisik dan sejumlah ketakutan serta kekhawatiran (A \& Griffin, 2005). Pendapat yang sama ditemukan oleh Damayanti (2014) pada saat ini hubungan bayi dengan keluarga sangat penting, jika keluarga memberi makan, membuatnya hangat, memeluk dan mengajak bicara maka bayi tersebut merasa kehadirannya dapat diterima. Sebaiknya kalau keluarga tidak dapat memenuhi kebutuhan bayi maka dalam diri bayi timbul ketidakpercayaan. Hal ini sesuai dengan pendapat Djaali (2008) jika anak dibimbing dengan baik maka penyesuaian sosial anak akan baik. Sari (2014) menyatakan bahwa sikap merupakan salah satu faktor predisposisi dari perilaku. Sikap ibu yang baik mempunyai pengaruh yang baik terhadap perilaku ibu dalam stimulasi perkembangan anak usia 0-12 bulan. Sedangkan sikap ibu yang kurang menyebabkan pemberian rangsangan untuk pertumbuhan dan perkembangan jasmani dan rohani yang kurang maksimal. 
Pada responden HM, HM akan meniru hal-hal yang dilihat seperti diperlihatkan muka jelek, ketika diminta untuk melakukan muka jelek, maka HM akan "mengerutkan keningnya atau menganga". Penelitian yang sama dilakukan oleh (Ariawan \& Marthyane, 2018) bahwa pada tahap kontraksi (contraction stage) terjadi antara usia 10-14 bulan, bayi akan memperoleh langkah dan irama bahasa serta belajar meniru hal yang mereka dengar. Nurmalitasari (2015) mengungkapkan perkembangan sosial adalah perkembangan tingkah laku pada anak dimana anak diminta untuk menyesuaikan diri dengan aturan yang berlaku dalam lingkungan masyarakat. Perkembangan sosial anak sangat dipengaruhi oleh proses perlakuan atau bimbingan orangtua terhadap anak dalam memperkenalkan berbagai aspek kehidupan sosial dan norma dalam masyarakat.

Hasil dalam penelitian juga menunjukkan bahwa responden sudah mampu berbicara dengan berceloteh, seperti pada responden HM yang mengatakan "eggi" ketika hendak ingin pergi. Menurut Sumiyati (2018) dalam aspek perkembangan sosial emosional anak usia 9-12 bulan, anak sudah dapat mengungkapkan sesuatu dengan cara sederhana yang biasa disebut dengan baby talk atau bahasa bayi pada usia 9-12 bulan dan anak sudah mulai untuk menyatakan perasaan dengan tindakan seperti memeluk, mencium atau bahkan merengek. Hal yang sama diungkapkan Hidayati (2012) bahwa pada kemampuan aspek sosial anak, anak usia 0-12 bulan cenderung menyatakan perasaannya secara fisik seperti, memeluk, menepuk dan mencium orang-orang terdekatnya atau orang-orang yang mereka kenal. Menurut Dewi (2019) menyatakan bahwa perkembangan sosial anak yang berkaitan dengan kemampuan anak perlu diberikan rangsangan atau stimulasi sejak dini, agar perkembangan sosial anak dapat mengarah pada perilaku yang membuat anak diterima di lingkunganya.

Berdasarkan hasil wawancara dan observasi kepada orangtua subjek dalam penelitian ini dapat diketahui bahwa kedua responden memiliki usia yang sama namun berbeda dalam tiap capaian perkembangannya. Sehingga ditemukan bentuk stimulasi yang orangtua terapkan pada anak yaitu: (1) membangun kelekatan dengan anak; (2) mengajak anak untuk bercakap-cakap atau berinteraksi dengan orang terdekat; dan (3) mengajak anak untuk bermain dengan teman sebayanya. Dengan adanya pengetahuan dalam memberikan stimulasi yang diberikan kepada anak sehingga menghasilkan perkembangan anak yang baik. Menimbulkan kesadaran pada anak yang menyebabkan anak berperilaku sesuai dengan tingkat usianya.

\section{SIMPULAN DAN SARAN}

Stimulasi merupakan suatu kegiatan yang dilakukan untuk merangsang kemampuan dasar anak agar anak dapat tumbuh dan berkembang secara optimal. Stimulasi tumbuh kembang anak dapat dilakukan oleh setiap orang yang sedang berinteraksi dengan anak, baik itu Ibu, Ayah, keluarga, maupun teman sebaya dalam kehidupan sehari-hari. Dengan demikian pentingnya pemberian stimulasi kepada anak sedini mungkin dan terus-menerus dapat mencegah terjadinya penyimpangan atau gangguan pada tumbuh kembang anak.

Hasil penelitian ini dapat disimpulkan bahwa setiap anak mencapai tingkat keberhasilan dalam mengembangkan aspek perkembangan sosialnya dikarenakan peran orang tua dan orang terdekat yang memberikan stimulasi yang sesuai dengan tingkat usia anak dan tahap perkembangannya. Dalam aspek perkembangan sosial emosional anak usia 9-12 bulan, anak dapat mengungkapkan sesuatu dengan cara sederhana yang disebut dengan bahasa bayi dan dapat menyatakan perasaan dengan tindakan seperti memeluk, mencium atau bahkan merengek. Dengan demikian, maka disarankan agar orangtua dapat 
memperhatikan dan memberikan stimulasi yang tepat dan sesuai dengan tingkat usia anak. Bentuk stimulasi yang dilakukan orangtua atau pengasuh anak dalam penelitian ini dapat direkomendasikan dilakukan oleh orangtua atau pengasuh lainnya yakni berupa: (1) membangun kelekatan dengan anak; (2) mengajak anak bercakap-cakap atau berinteraksi dengan orang terdekat; dan (3) mengajak anak untuk bermain dengan teman sebayanya.

\section{AKNOWLEDGMENT}

Penelitian ini di dukung oleh Fakultas Tarbiyah dan Keguruan UIN Alauddin Makassar.

\section{DAFTAR RUJUKAN}

A, P. P., \& Griffin, P. A. (2005). Fundamental Keperawatan Konsep, Proses dan Praktik. Edition 4 cetakan 1. Jakarta: EGC.

Adriana, D. (2013). Tumbuh Kembang \& Terapi Bermain Pada Anak. Jakarta: Penerbit Salemba Medika.

Apriani, D. (2018). Hubungan Peran Ibu Sebagai Pendidik Dalam Kemampuan Anak Autisme Usia 4-5 Tahun Di Yayasan Pembinaan Anak Cacat (YPAC) Palembang. Jurnal Masker Medika, 6(1), 140-155.

Ariawan, V. A. N., \& Marthyane, I. (2018). Dialogic Reading Sebagai Upaya Mengembangkan Keterampilan Berbahasa Anak Usia Dini. JAPRA: Jurnal Pendidikan Raudhatul Athfal, 1(1), 79-86.

Damayanti, R. (2014). Pengaruh Terapi Kelompok Terapaeutik Terhadap Kemampuan Keluarga Dalam Memberikan Stimulasi Perkembangan Rasa Percaya Usia Bayi Di Kelurahan Batu Ampar Kramatjati Jakarta Timur Tahun 2010. KONSELI: Jurnal Bimbingan Dan Konseling (E-Journal), 1(2), 67-76.

Dewi, M. S. (2019). Profil Perkembangan Sosial Anak Kelompok B Dalam Bermain Peran. Thufuli: Jurnal Pendidikan Islam Anak Usia Dini, 1(1), 35-45.

Djaali. (2008). Psikologi Pendidikan. Jakarta: Bumi Aksara.

Eliasa, E. I. (2011). Pentingnya Kelekatan Ibu Dalam Internal Working Model Untuk Pembentukan Karakter Anak. Psikologi Pendidikan dan Bimbingan Universitas Negeri Yogyakarta.

Fauzriesa, S. (2018). Hubungan Stimulasi Orang Tua Terhadap Perkembangan Bahasa Anak Usia 0-3 Tahun Di Wilayah Kerja Poskeskel Penengahan Raya Kecamatan Kedaton Bandar Lampung. Pendidikan Dokter Universitas Lampung.

Fida, \& Maya. (2012). Pengantar Ilmu Kesehatan Anak. Jogyakarta: D-Medika.

Hardiyanti, D. (2017). Proses Pembentukan Kelekatan Pada Bayi. Ivet Teacherpreneur, 24(2), 1-10.

Hasiana, I., Insani, A., Aisyah, \& Fachrurrazi, A. (2020). Optimalisasi Lingkungan Sekitar Sebagai Sumber Belajar Anak Usia Dini Di Desa Tawar Kecamatan Gondang Kabupaten Mojokerto. Jurnal Abadimas Adi Buana, 4(1), 29-34.

Hati, F. S., \& Lestari, P. (2016). Pengaruh Pemberian Stimulasi Pada Perkembangan Anak Usia 12-36 Bulan di Kecamatan Sedayu, Bantul. Jurnal Ners Dan Kebidanan Indonesia, 4(1), 44-48.

Hidayati, N. (2012). Bermain Khayal Untuk Mengembangkan Dimensi Sosioemosi Anak-Anak Prasekolah. Jurnal Insan Media Psikologi, 12(2), 104-112.

Kemendikbud. (2014). Peraturan Menteri Pendidikan Dan Kebudayaan Republik Indonesia Nomor 137 Tahun 2014 Tentang Standar Nasional Pendidikan Anak Usia Dini. 
Megawangi, R. (2014). Kelekatan Ibu-Anak "Kunci Membangun Bangsa." Depok: Indonesia Heritage Foundation (IHF).

Mitayani, Y., \& Nursetiawati, S. (2015). Hubungan Stimulasi Ibu Dengan Perkembangan Motorik Pada Anak Usia 2-3 Tahun (Toddler). Jurnal Kesejahteraan Keluarga Dan Pendidikan, 2(1), 59-67.

Nurmalitasari, F. (2015). Perkembangan Sosial Emosi Pada Anak Usia Prasekolah. Buletin Psikologi, 23(2), 203-111.

Permono, H. (2013). Peran Orangtua Dalam Mengoptimalisasi Tumbuh Kembang Anak Untuk Membangun Karakter Anak Usia Dini. Universitas Muhammadiyah Surakarta.

Putra, A. Y., Yudiernawati, A., \& Maemunah, N. (2018). Pengaruh Pemberian Stimulasi Oleh Orangtua Terhadap Perkembangan Bahasa Pada Usia Toddler di PAUD Asparaga Malang. Nursing News: Jurnal Ilmiah Keperawatan, 3(1), 563-571.

RI, K. (2012). Manajemen Laktasi: Buku Panduan Bagi Bidan dan Petugas Kesehatan di Puskesmas. Jakarta: Diit Gizi Masyarakat-Kemenkes RI.

Ribek, N., Labir, I. K., \& Dewi, I. D. A. P. C. (2013). Lingkaran Kepala Dengan Masa Perkembangan Pada Bayi Usia 0-12 Bulan. Jurnal Gena Keperawatan, 6(1), 72-76.

Rusmil, K. (2006). Pedoman Pelaksanaan Stimulasi, Deteksi dan Intervensi Dini Tumbuh Kembang Anak. Jakarta: Depkes RI.

Sari, D. E., \& Khusnal, E. (2014). Hubungan Tingkat Pengetahuan, Sikap Dengan Perilaku Ibu Dalam Stimulasi Perkembangan Anak Usia 0-12 Bulan Di Puskesmas Mergangsan Kota Yogyakarta. Sekolah Tinggi Ilmu Kesehatan 'Aisyiyah Yogyakarta.

Setyowati, H. S. E. (2017). Meningkatkan Hasil Belajar IPA Materi Energi Panas dan Energi Bunyi Menggunakan Kombinasi Model Numbered Heads Together (NHT), Problem Solving dan Picture Pada Siswa Kelas IV SDN Landasan Ulin Tengah 1 Kota Banjarbaru. Jurnal Pendidikan Prasekolah, 1(2), 69-74. https://www.rumahjurnal.net/index.php/JPP/article/view/227

Soetjiningsih. (2013). Tumbuh Kembang Anak Edisi 2. Jakarta: EGC.

Suhano, \& Utama, F. (2017). Keteladanan Orang Tua dan Guru dalam Pertumbuhan dan Perkembangan Anak Usia Dini. Elementary: Jurnal Ilmiah Pendidikan Dasar, 3(2), 107-119.

Suherman. (2002). Perkembangan Anak. Jakarta: EGC.

Sulfa, F. F., \& Setiawan, M. H. Y. (2018). Optimalisasi Peran Orang Tua Dalam Mengembangkan Potensi PAUD. Adi Widya: Jurnal Pengabdian Masyarakat, 2(2), $178-184$.

Sumiyati. (2018). Mengenal Pertumbuhan dan Perkembangan Anak Usia Dini (Usia 012 Bulan). Al-Athfal, 1(1), 18-36.

Sumiyati, \& Yuliani, D. R. (2016). Hubungan Stimulasi Dengan Perkembangan Anak Usia 4-5 Tahun Di Desa Karangtengah Kecamatan Baturraden Kabupaten Banyumas. Jurnal LINK, 12(1), 34-38.

Va, K. D. (2016). Konsep Gerak Dasar Untuk Usia Dini. Jurnal Pendidikan Kesehatan Rekreasi, 2(1), 72-79. 


\section{AUTHOR}

Eka Damayanti berasal dari Makassar dan sekarang aktif sebagai dosen di Pogram Studi Pendidikan Islam Anak Usia Dini Fakultas Tarbiyah dan Keguruan UIN Alauddin Makassar. Email: eka.damayanti@uin-alauddin.ac.id.

Umaemah Marsuki AR berasal dari Barru dan sekarang masih aktif sebagai mahasiswa Program Studi Pendidikan Islam Anak Usia Dini (PIAUD) Fakultas Tarbiyah dan Keguruan di UIN Alauddin Makassar. Email: umaemahema24@gmail.com.

Ismawati berasal dari Bulukumba dan sekarang masih aktif sebagai mahasiswa semester akhir Program Studi Pendidikan Islam Anak Usia Dini (PIAUD) Fakultas Tarbiyah dan Keguruan di UIN Alauddin Makassar. Email: 20900116030@uin-alauddin.ac.id 